\title{
Trends in sweetened beverages consumption among adults in the Brazilian capitals, 2007-2016
}

\author{
Natasha Figueiredo ${ }^{1, *}$, Emanuella Gomes Maia ${ }^{2}$, Luiza Eunice Sá da Silva ${ }^{3}$, \\ Fernanda Serra Granado ${ }^{4}$ and Rafael Moreira Claro ${ }^{5}$ \\ ${ }^{1}$ Federal University of Minas Gerais, Nutrition Undergraduate Course, Avenida Professor Alfredo Balena 190, Santa \\ Efigênia, Belo Horizonte, MG, Brazil, CEP 30130-100: ${ }^{2}$ Federal University of Minas Gerais, Nursing Postgraduate \\ Program, Belo Horizonte, MG, Brazil: ${ }^{3}$ Federal University of Minas Gerais, Nutrition and Health Postgraduate \\ Course, Belo Horizonte, MG, Brazil: ${ }^{4}$ Federal University of Minas Gerais, Center for Labor and Health Studies, Belo \\ Horizonte, MG, Brazil: ${ }^{5}$ Federal University of Minas Gerais, Department of Nutrition, Belo Horizonte, MG, Brazil
}

Submitted 9 March 2018: Final revision received 26 June 2018: Accepted 1 August 2018: First published online 12 September 2018

\begin{abstract}
Objective: To analyse trends in sweetened beverages consumption among adults in Brazil between 2007 and 2016.

Design: A time-series analysis, with data from the Surveillance System of Risk and Protection Factors for Chronic Diseases by Telephone Survey (VIGITEL). The prevalence of regular consumption ( $\geq 5 \mathrm{~d}$ /week), the average daily consumption (millilitres) and the prevalence of non-consumption of these beverages were analysed. The temporal variations of the indicators were calculated by linear regression. The analyses were performed for the complete set of the evaluated population and stratified by sociodemographic characteristics.

Setting: Brazilian capitals and Federal District.

Subjects: Brazilian adults aged $\geq 18$ years ( $n$ 519641).

Results: There was a reduction in both regular and average daily consumption of sugar- and artificially sweetened beverages $(-1.28$ percentage points (pp)/year, $P=0.001$ and $-9.63 \mathrm{ml} /$ year, $P=0.001$, respectively). The same result regarding regular consumption was found when only sugar-sweetened beverages were analysed $(-1 \cdot 11 \mathrm{pp} /$ year, $P=0 \cdot 011)$. Similar trends were identified in the stratified analyses, with a greater magnitude of reduction among males, young adults, those with higher schooling and residents of more developed regions. Coincidentally, there was an increase in the prevalence of adults who did not consume sweetened beverages (1.54 pp/year, $P=0.005)$.

Conclusions: The consumption of sweetened beverages decreased during the period. However, a significant portion of the population still referred a daily consumption of these beverages.
\end{abstract}

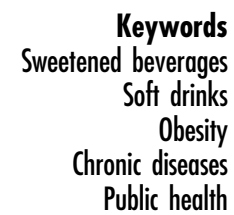

ords beverages Obesity Public health
Over the past decades, non-communicable diseases (NCD) have been emphasized as a major public health problem, since they represent the leading cause of death and disability among populations in developed and developing countries ${ }^{(1-3)}$. In 2016, these diseases accounted for about three out of four deaths on a global scale $(72.3 \%)$, with a similar scenario in Brazil $(76.4 \%)^{(4)}$. This situation is partially driven by increases in the prevalence of overweight and obesity ${ }^{(5-7)}$, which, in 2015, were directly responsible for about 4 million deaths worldwide ${ }^{(8)}$. In Brazil, the prevalence of overweight went up from $31 \cdot 1 \%$ in 1980 to $56.5 \%$ in 2016 , while the rise in the prevalence of obesity was even more critical, from $6.6 \%$ in 1980 to $23.1 \%$ in 2016 , representing an increase of more than $300 \%$ in about 35 years $^{(4)}$.

The dietary pattern related to excessive weight gain and NCD is characterized by the high consumption of ultraprocessed foods to the detriment of fresh and minimally processed foods ${ }^{(9)}$. Ultra-processed foods are commonly rich in free sugars (monosaccharides and disaccharides added to foods and beverages by the manufacturer, cook or consumer, and sugars naturally present in honey, syrups, fruit juices and fruit juice concentrates) ${ }^{(10)}$. In Brazil, between 1987 and 2009, the consumption of ultraprocessed foods and beverages (such as sweetened beverages (SB), biscuits and chips) increased significantly (from 18.7 to $29.6 \%$ ), while the consumption of fresh and 
minimally processed foods (such as rice, beans, vegetables, eggs, roots and tubers) reduced from 44.0 to $38.9 \%{ }^{(11)}$.

Among these products, SB (especially soft drinks and artificial juices) have a recognized relationship with excessive weight gain and $\mathrm{NCD}^{(12-15)}$. Extensive literature endorses this connection, highlighting not only the extremely low nutritional value of these beverages, but also their reduced capacity to promote satiety proportionally to their energy content (in comparison to solid items) ${ }^{(16)}$. SB tend to figure among the major dietary sources of free sugars in both developing and developed countries $^{(17-19)}$. In 2009, free sugars consumption in Brazilian households reached $16.7 \%$ of total energy ${ }^{(20)}$, exceeding by $67 \%$ the WHO recommended daily limit for adults $\left(10 \%\right.$ of total energy) ${ }^{(10)}$. Although table sugar is still the major contributor to this high sugar consumption, the increase of about $200 \%(0.8$ to $2 \cdot 2 \%)$ in the contribution of SB to the total energy purchased by Brazilian households from 1987 to 2009 must be highlighted ${ }^{(11)}$. Current evidence also indicates potential health risks related to the consumption of artificially sweetened beverages (ASB), such as diet, light and zero versions, proving these products are unlikely to be healthy alternatives to sugar-sweetened beverages (SSB) ${ }^{(21,22)}$. Thus, reduction in the consumption of both types of SB has been discussed as a way of curbing current levels of obesity and NCD in Brazil ${ }^{(1,23)}$.

As no national food consumption survey is available in the country since 2009, current estimates for the Brazilian adult population rely mostly on data from the Surveillance System of Risk and Protective Factors for Chronic Diseases by Telephone Survey (VIGITEL) ${ }^{(24)}$. Therefore, the objective of the present study was to analyse time trends in SB consumption among adults in the Brazilian capitals and the Federal District (FD) between 2007 and 2016.

\section{Methods}

\section{Sampling and data collection}

The current study is a time-series analysis based on data from VIGITEL between 2007 and 2016, totalling 519641 interviews. This system was implemented in 2006 by the Ministry of Health to investigate, annually, risk and protective factors for NCD among the adult population (age $\geq 18$ years) of all state capitals and $\mathrm{FD}^{(24)}$.

Information about the population's health is obtained through annual telephone surveys, in which a sample of approximately 2000 individuals is interviewed in each city per year of system operation, so the risk and protective factors for NCD can be assessed with a 95\% CI and a sample error of 2 percentage points (pp). For specific estimates, by gender, a maximum of $3 \mathrm{pp}$ is expected. The VIGITEL sampling process is performed in two stages. The first consists in the sampling of 5000 landline telephones per city, followed by reorganization in twenty-five replicas, each replica reproducing the same proportion of lines by postal code (ZIP code) of the original list. Each landline selected is contacted up to six times in distinct days and hours (from 09.00 to 21.00 hours, including weekends and holidays) to verify its eligibility. Non-residential lines, out-of-service lines and lines that do not answer to any attempt of contact are considered ineligible. At the second stage, one adult among the residents of each household is sampled (simple random sample) and invited to participate to the survey.

According to the last national Demographic Census, in 2010, landlines telephones reached $60 \cdot 8 \%$ (varying from 28.5 to $74.2 \%$ ) of the households existing in all twenty-six Brazilian capitals and FD. Refusal rate was low, about $4.1 \%$ (varying from $2 \cdot 2$ to $5.8 \%$ ). Weighting factors provided by the Ministry of Health equate the distribution of the population interviewed by VIGITEL with that predicted for the entire adult population of each city. The weighting procedure is executed in two steps. The first step aims to correct the unequal probability of selection of households with more than one landline telephone or with more than one resident, and the second step aims to equate the distribution of the population interviewed in each city (by gender, age and schooling) to its entire population (based on the official projections for each year) ${ }^{(24)}$.

The interviews were conducted through a computerassisted telephone interview system, where questions were directly read from the screen of a video monitor and the answers were immediately recorded in an electronic form by a previously trained interviewer. This process allows not only the immediate discrimination of invalid responses and timing of the interview, but also the automatic pass-through over issues that are not applicable due to previous responses and the continuous feeding into the system database ${ }^{(24)}$.

Questions about sociodemographic characteristics, smoking, overweight and obesity, food consumption, physical activity, alcoholic beverages consumption, selfassessment of health status, female cancer screening tests and referred morbidity are addressed in the VIGITEL system. Food consumption was investigated through questions regarding the intake of markers of healthy and unhealthy lifestyles. SB were taken as an unhealthy marker ${ }^{(25)}$. More details on the sampling process and data collection employed by VIGITEL can be obtained from the annual reports of the system ${ }^{(24)}$.

\section{Variables of study and organization of data}

Sweetened beverages (SB) were classified as: sugarsweetened beverages (SSB), i.e. regular soft drinks and artificial juices; and artificially sweetened beverages (ASB), i.e. diet, light or zero soft drinks and artificial juices. 
The information regarding the consumption of SB was investigated by VIGITEL from 2007 onwards through three questions: 'How many days a week, do you usually drink soft drinks or artificial juices? ( 1 to 2 days a week; 3 to 4 days a week; 5 to 6 days a week; every day, including Saturday and Sunday; almost never; never)'; 'What type? (regular; diet/light/zero; both)'; 'How many glasses/cans do you usually drink per day? $(1 ; 2 ; 3 ; 4 ; 5 ; 6$ or more; I don't know)'. The question regarding the type of beverage consumed was omitted in 2012, 2013 and 2014.

Two indicators were developed to represent the regular consumption ( $\geq 5 \mathrm{~d} /$ week, independently of the quantity consumed) of SB and SSB. Average daily consumption of SB (millilitres per capita) was estimated by multiplying the weekly prevalence of consumption (mean value of the reported range) by the average amount consumed on a given day, and then dividing the result by 7 (number of days in a week). Only individuals with one or more days of consumption of SB per week were considered. Finally, a complementary indicator was created to represent nonconsumption of SB (consumption reported as 'almost never' and 'never').

A set of five sociodemographic variables complemented the analysis: gender (male; female), age group in years (18-24; 25-34; 35-44; 45-54; 55-64; $\geq 65$ ), schooling in years of study $(0-8 ; 9-11 ; \geq 12$ years), marital status (with partner; without partner) and geographical region (North and Northeast (less developed regions); Midwest, Southeast and South (more developed regions)).

\section{Data analysis}

The studied population was initially described according to its sociodemographic characteristics. The prevalence of regular consumption of $\mathrm{SB}$ and $\mathrm{SSB}$, the average daily consumption of SB and the prevalence of nonconsumption of SB were then estimated for each year. All analyses were conducted for the entire population and according to sociodemographic strata.

The presence of significant linear trends was investigated through linear regression models. For each year, the dependent variables were all four indicators (annual prevalence of regular consumption of $\mathrm{SB}$; annual prevalence of regular consumption of SSB; annual average daily consumption of SB; annual prevalence of nonconsumption of SB) and the independent variables were the years of data collection. The statistical significance of the trends was evaluated using the regression coefficient, which indicates the annual average rate of increase or decrease of each (expressed in percentage points per year or millilitres per year). Variations corresponding to a regression coefficient statistically different from zero $(P<0.05)$ were considered significant.

The statistical software package Stata version 13.1 was used to organize, process and analyse the data, considering the design of the VIGITEL sample at all stages.
The VIGITEL was approved by the National Commission of Ethics in Research for Human Beings of the Ministry of Health (CONEP Opinion 355.590 of 26 June 2013 and certificate of presentation for ethics assessment (CAAE) no. 16202813.2.0000.0008). Data are freely available for public access and use and do not allow identification of the respondents ${ }^{(24)}$.

\section{Results}

A total of 519641 adults from the Brazilian capitals and FD were interviewed by VIGITEL from 2007 to 2016. Most of them were young adults (25-44 years old, about $45.3 \%$ ) with up to 11 years of study (about $75.3 \%$ ). The distribution of the population in terms of marital status was similar throughout the period and about two-thirds resided in more developed regions. Significant changes were observed in the prevalence of individuals in the older age groups ( 45 years or older: from 35.9 to $40.6 \%, P<0.001$ ) and with higher schooling (more than 9 years of study: from 54.9 to $67.5 \%$; $9-11$ years: $P=0.038 ; 12$ years or more: $P<0 \cdot 001)$. There was also a significant increase in the prevalence of unmarried individuals ( 47.5 to $52.2 \%$, $P=0.005)$ and those living in less developed regions (33.6 to $35.3 \%, P=0.008$; Table 1 ).

In the complete set of the population, there was a significant reduction of regular consumption $(\geq 5 \mathrm{~d} /$ week $)$ of $\mathrm{SB}$, from 30.9 to $16.5 \%(-1.28 \mathrm{pp} /$ year, $P=0.001)$ during the 10 years analysed. The decline in consumption was even more pronounced in the most recent period (2012-2016: $-2.32 \mathrm{pp} /$ year, $P<0 \cdot 001)$. A similar trend was observed in all population strata. Greater reductions were observed among men $(-1.37 \mathrm{pp} /$ year, $P=0.001)$, those with age between 18 and 44 years (18-24 years: $-1.46 \mathrm{pp} /$ year, $P=0.016$; 25-34 years: -1.68 pp/year, $P<0.001$; 35-44 years: $-1.22 \mathrm{pp} /$ year, $P=0 \cdot 001)$, with more than 12 years of study $(-1.70 \mathrm{pp} /$ year, $P<0.001)$, with a partner $(-1.33 \mathrm{pp} /$ year, $P<0.001)$ and residents of more developed regions $(-1.36 \mathrm{pp} /$ year, $P=0.001$; Table 2$)$.

Among the individuals who reported regular consumption ( $\geq 5 \mathrm{~d}$ /week) of SB, $90 \%$ consumed SSB (data not shown). The prevalence of regular consumption of SSB also decreased significantly, from $26 \cdot 3$ to $14 \cdot 7 \%(-1 \cdot 11$ $\mathrm{pp} /$ year, $P=0 \cdot 011)$. Once again, reduction was observed in all strata, with a marked reduction among men $(-1.24$ pp/year, $P=0 \cdot 013)$, young adults (18-24 years: $-1.29 \mathrm{pp} /$ year, $P=0.040 ; 25-34$ years: -1.39 pp/year, $P=0.005$; 35-44 years: $-1.11 \mathrm{pp} /$ year, $P=0.037)$, those with schooling between 9 and 11 years of study $(-1 \cdot 17 \mathrm{pp} /$ year, $P=0.013)$, with a partner $(-1.18 \mathrm{pp} /$ year, $P=0.006)$ and resident in more developed regions $(-1.14$ pp/year, $P=0 \cdot 011$; Table 3).

The average daily consumption also decreased significantly. In 2007, Brazilians consumed an average of $430.4 \mathrm{ml} \mathrm{SB} / \mathrm{d}$ and in 2016, this consumption declined to 
Table 1 Distribution $\dagger$ of the adult population (aged $\geq 18$ years) from the Brazilian capitals and Federal District by sociodemographic variables. VIGITEL, 2007-2016

\begin{tabular}{|c|c|c|c|c|c|c|c|c|c|c|c|c|}
\hline \multirow[b]{2}{*}{ Variable } & \multicolumn{10}{|c|}{ Distribution of the studied population (\%) } & \multirow{2}{*}{$\begin{array}{l}\text { Incremental average, } \\
\text { 2007-2016 (pp/year) }\end{array}$} & \multirow[b]{2}{*}{$P$ value } \\
\hline & 2007 & 2008 & 2009 & 2010 & 2011 & 2012 & 2013 & 2014 & 2015 & 2016 & & \\
\hline Total $(n)$ & 55824 & 54353 & 54367 & 54339 & 54144 & 45448 & 52929 & 40853 & 54174 & 53210 & & \\
\hline \multicolumn{13}{|l|}{ Gender } \\
\hline Male & $46 \cdot 2$ & $46 \cdot 1$ & $46 \cdot 1$ & $46 \cdot 1$ & $46 \cdot 1$ & $46 \cdot 1$ & $46 \cdot 1$ & $46 \cdot 1$ & $46 \cdot 0$ & $46 \cdot 0$ & $-0.01^{*}$ & 0.011 \\
\hline Female & $53 \cdot 8$ & $53 \cdot 9$ & $53 \cdot 9$ & 53.9 & 53.9 & 53.9 & 53.9 & 53.9 & 54.0 & 54.0 & $0.01^{*}$ & 0.011 \\
\hline \multicolumn{13}{|l|}{ Age (years) } \\
\hline $18-24$ & $18 \cdot 2$ & $17 \cdot 9$ & $17 \cdot 2$ & $17 \cdot 1$ & $16 \cdot 7$ & $16 \cdot 4$ & $15 \cdot 9$ & $15 \cdot 6$ & $15 \cdot 2$ & $14 \cdot 8$ & $-0.37^{\star}$ & $<0.001$ \\
\hline $25-34$ & $25 \cdot 4$ & 25.4 & $25 \cdot 5$ & $25 \cdot 4$ & $25 \cdot 4$ & $25 \cdot 2$ & $25 \cdot 3$ & $25 \cdot 3$ & $25 \cdot 2$ & $25 \cdot 2$ & $-0.03^{\star}$ & 0.004 \\
\hline $35-44$ & 20.5 & $20 \cdot 4$ & $20 \cdot 3$ & $20 \cdot 1$ & $20 \cdot 0$ & $19 \cdot 9$ & $19 \cdot 7$ & $19 \cdot 6$ & $19 \cdot 4$ & $19 \cdot 3$ & $-0.14^{*}$ & $<0.001$ \\
\hline $45-54$ & $15 \cdot 9$ & $16 \cdot 1$ & $16 \cdot 3$ & $16 \cdot 4$ & $16 \cdot 6$ & $16 \cdot 8$ & $16 \cdot 9$ & $17 \cdot 1$ & $17 \cdot 3$ & $17 \cdot 4$ & $0 \cdot 16^{*}$ & $<0.001$ \\
\hline $55-64$ & $10 \cdot 2$ & $10 \cdot 4$ & $10 \cdot 7$ & $10 \cdot 9$ & $11 \cdot 1$ & 11.4 & 11.6 & $11 \cdot 8$ & $12 \cdot 1$ & $12 \cdot 3$ & $0.24^{*}$ & $<0.001$ \\
\hline$\geq 65$ & 9.8 & 9.8 & $10 \cdot 0$ & $10 \cdot 1$ & $10 \cdot 2$ & $10 \cdot 4$ & 10.5 & $10 \cdot 6$ & $10 \cdot 8$ & $10 \cdot 9$ & $0.14^{*}$ & $<0.001$ \\
\hline \multicolumn{13}{|l|}{ Schooling (years) } \\
\hline $0-8$ & $45 \cdot 0$ & $43 \cdot 7$ & $42 \cdot 0$ & $40 \cdot 6$ & $38 \cdot 8$ & $36 \cdot 8$ & $36 \cdot 6$ & $35 \cdot 9$ & $34 \cdot 6$ & 32.5 & $-1 \cdot 34^{*}$ & $<0.001$ \\
\hline $9-11$ & $35 \cdot 1$ & 34.7 & 35.8 & 35.8 & $36 \cdot 7$ & 38.5 & 37.5 & 38.1 & $38 \cdot 1$ & 35.9 & $0.30^{*}$ & 0.007 \\
\hline$\geq 12$ & $19 \cdot 8$ & $21 \cdot 6$ & $22 \cdot 2$ & 23.5 & 24.5 & 24.7 & $25 \cdot 9$ & $25 \cdot 9$ & $27 \cdot 3$ & 31.6 & $1.04^{*}$ & $<0.001$ \\
\hline \multicolumn{13}{|l|}{ Marital status } \\
\hline With partner & 52.5 & $50 \cdot 2$ & $51 \cdot 3$ & $51 \cdot 6$ & $49 \cdot 3$ & 51.0 & 48.8 & $50 \cdot 3$ & $47 \cdot 7$ & 47.8 & $-0.43^{\star}$ & 0.005 \\
\hline Without partner & 47.5 & $49 \cdot 8$ & $48 \cdot 7$ & $48 \cdot 4$ & $50 \cdot 7$ & $49 \cdot 0$ & $51 \cdot 2$ & $49 \cdot 7$ & $52 \cdot 3$ & $52 \cdot 2$ & $0.43^{*}$ & 0.005 \\
\hline \multicolumn{13}{|l|}{ Geographic region } \\
\hline $\begin{array}{l}\text { North and } \\
\text { Northeast }\end{array}$ & $33 \cdot 6$ & $34 \cdot 8$ & 34.9 & $34 \cdot 8$ & $34 \cdot 9$ & $35 \cdot 0$ & $35 \cdot 1$ & $35 \cdot 2$ & $35 \cdot 2$ & $35 \cdot 3$ & $0 \cdot 13^{*}$ & 0.008 \\
\hline $\begin{array}{l}\text { Midwest, } \\
\text { Southeast } \\
\text { and South }\end{array}$ & $66 \cdot 4$ & $65 \cdot 2$ & $65 \cdot 1$ & $65 \cdot 2$ & $65 \cdot 1$ & $65 \cdot 0$ & $64 \cdot 9$ & $64 \cdot 8$ & $64 \cdot 8$ & $64 \cdot 7$ & $-0.13^{\star}$ & 0.008 \\
\hline
\end{tabular}

VIGITEL, Surveillance System of Risk and Protective Factors for Chronic Diseases by Telephone Survey; pp, percentage points.

${ }^{*} P<0.05$.

†Weighted percentage to adjust the sociodemographic distribution of the VIGITEL sample to the distribution of the adult population of each city estimated for each year of study.

$\ddagger$ Corresponding to the linear regression coefficient value of the indicator on the year of the survey.

$287.6 \mathrm{ml} / \mathrm{d}(-9.63 \mathrm{pp} / \mathrm{year}, P=0.001)$. The reduction was larger in the most recent period $(-16.94 \mathrm{pp} / \mathrm{year}$, $P=0.004)$. Over the 10 years analysed, the decline in the amount consumed was also significant for all strata, except for the most recent period (2012-2016) among adults aged 55 years or over. Unlike the prevalence of regular consumption (Table 2), the average daily consumption in the total period (2007-2016) decreased most intensely among those with 11 years or less of schooling ( $0-8$ years: $-8 \cdot 40$ pp/year, $P=0 \cdot 014$; 9-11 years: $-10 \cdot 20$ pp/year, $P=0 \cdot 002$; Table 4).

Conversely, there was a significant increase in the prevalence of individuals who did not consume $\mathrm{SB}$ in the entire population $(30.4$ to $34.2 \%, 1.54 \mathrm{pp} /$ year, $P=0.005$ ) and in strata analysed (except for individuals aged 65 years or over). This increase was more significant among women (1.76 pp/year, $P=0.005)$, with schooling higher than 12 years $(2 \cdot 13 \mathrm{pp} /$ year, $P=0.001)$ and residents of less developed regions ( $1.76 \mathrm{pp} /$ year, $P=0.004)$. There was a similar increase across different ages and marital status (Table 5).

\section{Discussion}

The systematic collection of information regarding the consumption of SB in a sample of more than half a million adults residing in all state capitals and FD over a 10-year period allowed the identification of a downward trend in the consumption of SB by the Brazilian adult population. There was a significant reduction in the regular consumption and average daily consumption of SB (more pronounced in the most recent period), as well as in the regular consumption of SSB throughout the total period. A similar trend was identified in all strata of the population, with a greater magnitude of reduction among men, with age between 18 and 44 years, individuals with higher level of education and residents of more developed regions. In the same sense, there was a significant increase in the prevalence of adults who did not consume any type of SB, especially among women, with higher schooling and residents of less developed regions. The magnitude of this increase was similar between different age groups.

The downward trend revealed among the results of the present study represents an inversion of the situation observed in the past decades in Brazil. Data from Household Budget Surveys conducted in the main metropolitan areas of the country since the 1980s show an increase in the participation of SB in total food and beverage acquisitions for household consumption (consumption away from home was not considered) from $0 \cdot 8 \%$ in 1987 to $2 \cdot 8 \%$ in 2003 . However, no further increase was observed in the most recent survey conducted in 2009 (consumption remained steady, at $2.7 \%$ ), 
Table 2 Prevalence $\dagger$ of the regular consumption ( $\geq 5 \mathrm{~d} /$ week) of sweetened beverages (including sugar- and artificially sweetened beverages) among the adult population (aged $\geq 18$ years) from the Brazilian capitals and Federal District by sociodemographic variables. VIGITEL, 2007-2016

\begin{tabular}{|c|c|c|c|c|c|c|c|c|c|c|c|c|c|c|}
\hline \multirow[b]{2}{*}{ Variable } & \multicolumn{10}{|c|}{ Prevalence of the regular consumption of sweetened beverages (\%) } & \multirow{2}{*}{$\begin{array}{l}\text { Incremental average, } \\
2007-2016 \\
\text { (pp/year) } \ddagger\end{array}$} & \multirow[b]{2}{*}{$P$ value } & \multirow{2}{*}{$\begin{array}{c}\text { Incremental average, } \\
2012-2016 \\
\text { (pp/year) } \ddagger\end{array}$} & \multirow[b]{2}{*}{$P$ value } \\
\hline & 2007 & 2008 & 2009 & 2010 & 2011 & 2012 & 2013 & 2014 & 2015 & 2016 & & & & \\
\hline \multicolumn{15}{|l|}{ Gender } \\
\hline Male & $35 \cdot 7$ & $30 \cdot 7$ & $29 \cdot 3$ & 30.0 & 32.0 & 29.8 & $26 \cdot 7$ & 23.9 & $22 \cdot 4$ & $19 \cdot 6$ & $-1 \cdot 37^{*}$ & 0.002 & $-2 \cdot 47^{*}$ & 0.001 \\
\hline Female & 26.9 & $22 \cdot 8$ & $23 \cdot 1$ & $24 \cdot 1$ & 23.6 & 22.7 & 20.4 & $18 \cdot 2$ & $16 \cdot 1$ & 13.9 & $-1 \cdot 20^{*}$ & 0.001 & $-2 \cdot 20^{*}$ & 0.000 \\
\hline \multicolumn{15}{|l|}{ Age (years) } \\
\hline $18-24$ & 43.2 & $36 \cdot 3$ & $36 \cdot 7$ & $35 \cdot 3$ & 39.6 & $36 \cdot 3$ & 33.2 & 28.9 & 30.2 & $24 \cdot 2$ & $-1.46^{*}$ & 0.006 & $-2 \cdot 73^{\star}$ & 0.016 \\
\hline $25-34$ & $37 \cdot 3$ & 34.3 & $32 \cdot 2$ & 34.1 & 32.8 & 31.9 & 29.8 & $25 \cdot 9$ & 23.8 & $20 \cdot 1$ & $-1.68^{*}$ & $<0.001$ & $-2 \cdot 96^{*}$ & $<0.001$ \\
\hline $35-44$ & 29.9 & 25.2 & $25 \cdot 3$ & 29.4 & 26.4 & $26 \cdot 6$ & 24.1 & 21.7 & 17.9 & $16 \cdot 9$ & $-1 \cdot 22^{*}$ & 0.009 & $-2 \cdot 55^{\star}$ & 0.001 \\
\hline $45-54$ & 24.6 & 20.3 & 20.0 & 20.4 & 22.8 & 21.6 & 17.5 & 17.8 & 14.2 & 12.7 & $-0.98^{*}$ & 0.011 & $-2 \cdot 13^{\star}$ & 0.008 \\
\hline $55-64$ & 18.3 & $16 \cdot 2$ & 16.0 & $14 \cdot 3$ & 18.6 & 15.8 & 13.2 & 11.8 & 11.9 & 10.5 & $-0.76^{\star}$ & 0.010 & $-1 \cdot 20^{*}$ & 0.017 \\
\hline$\geq 65$ & $17 \cdot 0$ & 11.2 & 13.0 & 12.9 & 14.1 & $12 \cdot 1$ & 11.4 & $10 \cdot 1$ & 9.4 & 9.9 & $-0.41^{*}$ & 0.036 & $-0.65^{\star}$ & 0.040 \\
\hline \multicolumn{15}{|l|}{ Schooling (years) } \\
\hline $0-8$ & $28 \cdot 1$ & $23 \cdot 6$ & $22 \cdot 8$ & $22 \cdot 9$ & $25 \cdot 3$ & 24.9 & $22 \cdot 1$ & 18.0 & $16 \cdot 6$ & $15 \cdot 9$ & $-1.04^{*}$ & 0.010 & $-2 \cdot 35^{*}$ & 0.008 \\
\hline $9-11$ & 34.4 & $29 \cdot 6$ & 28.9 & 30.7 & $30 \cdot 3$ & 27.9 & $25 \cdot 8$ & $24 \cdot 4$ & 22.5 & $18 \cdot 7$ & $-1 \cdot 33^{\star}$ & 0.001 & $-2 \cdot 17^{\star}$ & 0.003 \\
\hline$\geq 12$ & $31 \cdot 1$ & $27 \cdot 0$ & $27 \cdot 1$ & $27 \cdot 6$ & $26 \cdot 6$ & 24.5 & $21 \cdot 1$ & $19 \cdot 4$ & $16 \cdot 9$ & $14 \cdot 6$ & $-1 \cdot 70^{*}$ & $<0.001$ & $-2 \cdot 40^{*}$ & $<0.001$ \\
\hline \multicolumn{15}{|l|}{ Marital status } \\
\hline With partner & 32.9 & 28.8 & $27 \cdot 3$ & $27 \cdot 7$ & 28.9 & $27 \cdot 1$ & $24 \cdot 4$ & $22 \cdot 9$ & $20 \cdot 3$ & $17 \cdot 6$ & $-1 \cdot 33^{\star}$ & 0.001 & $-2 \cdot 31^{\star}$ & $<0.001$ \\
\hline Without partner & $29 \cdot 1$ & $24 \cdot 0$ & $24 \cdot 7$ & $25 \cdot 9$ & $26 \cdot 0$ & $24 \cdot 8$ & $22 \cdot 1$ & $18 \cdot 7$ & 17.5 & $15 \cdot 3$ & $-1 \cdot 25^{\star}$ & 0.003 & $-2 \cdot 37^{\star}$ & 0.001 \\
\hline \multicolumn{15}{|l|}{ Geographic region } \\
\hline $\begin{array}{l}\text { North and } \\
\text { Northeast }\end{array}$ & $27 \cdot 1$ & $20 \cdot 1$ & $20 \cdot 7$ & $21 \cdot 1$ & $21 \cdot 2$ & $19 \cdot 9$ & $18 \cdot 6$ & $15 \cdot 8$ & 14.5 & $11 \cdot 2$ & $-1 \cdot 12^{*}$ & 0.002 & $-2 \cdot 15^{\star}$ & 0.001 \\
\hline $\begin{array}{l}\text { Midwest, } \\
\text { Southeast } \\
\text { and South }\end{array}$ & $32 \cdot 9$ & 29.8 & $28 \cdot 8$ & 29.9 & 30.9 & 29.2 & $25 \cdot 8$ & 23.5 & $21 \cdot 4$ & $19 \cdot 4$ & $-1 \cdot 36^{*}$ & 0.001 & $-2 \cdot 41^{*}$ & 0.001 \\
\hline TOTAL & 30.9 & $26 \cdot 4$ & $26 \cdot 0$ & $26 \cdot 8$ & 27.5 & $26 \cdot 0$ & $23 \cdot 3$ & $20 \cdot 8$ & $19 \cdot 0$ & $16 \cdot 5$ & $-1 \cdot 28^{*}$ & 0.001 & $-2 \cdot 32^{*}$ & $<0.001$ \\
\hline
\end{tabular}

VIGITEL, Surveillance System of Risk and Protective Factors for Chronic Diseases by Telephone Survey; pp, percentage points.

${ }^{*} P<0.05$.

†Weighted percentage to adjust the sociodemographic distribution of the VIGITEL sample to the distribution of the adult population of each city estimated for each year of study.

$\ddagger$ Corresponding to the linear regression coefficient value of the indicator on the year of the survey.

contradicting the trend observed in most countries ${ }^{(11)}$. While more recent information is not available, as of 2010, external sources (industry balances and market researchers) also indicate reductions in the production of SB and demand retraction for these products ${ }^{(26-30)}$.

This reduction in the regular consumption and average daily consumption of $\mathrm{SB}$, together with the increase of non-consumption, may represent an improvement in quality of the Brazilian diet. However, the observed trends should not lead to the conclusion that health risks are surpassed, since in 2016 about one out of six adults (16.5\%) still consumed SB on a regular basis. This percentage represents almost 6 million individuals in the state capitals and FD (or about 26 million people when considering the entire adult population of $\mathrm{Brazil}^{(31)}$ ) consuming SB almost daily or even every day. Furthermore, inequities observed in the beginning of the studied period were not surpassed. Higher prevalence of consumption was seen among men, those in the younger age groups and in the higher schooling levels during the entire period. About $90 \%$ of individuals reporting regular consumption ( $\geq 5 \mathrm{~d}$ /week) of SB consumed SSB (exclusively or combined with ASB). This prevalence held similar during the entire study period (data not shown), indicating no substitution of SSB for those with reduced or null energy content.

The deleterious effects of SB consumption are widely highlighted in the scientific literature ${ }^{(10,32,33)}$. A longitudinal study published in 2004, involving more than 50000 Americans, identified that women who increased their consumption of SSB and maintained a high level of this consumption gained, on average, $8.0 \mathrm{~kg}$ of weight in a period of 8 years, while those who decreased their consumption and maintained a low level gained, in the same period, $2 \cdot 8 \mathrm{~kg}^{(34)}$. This causal relationship between $\mathrm{SB}$ consumption and excessive weight gain was also identified in other longitudinal studies ${ }^{(35,36)}$. In 2015, a metaanalysis with data from seventeen longitudinal studies (38253 individuals) identified an association between habitual SB consumption (one daily serving) and a higher incidence of type 2 diabetes mellitus (the incidence was $18 \%$ higher without adjustment for adiposity and 13\% higher after adjustment for potential mediators and confounders of adiposity) ${ }^{(22)}$. In 2016, another meta-analysis based on longitudinal studies (308420 individuals) indicated an association between SSB consumption and increased cardiovascular risk ${ }^{(37)}$. Also, a growing body of evidence has refuted the effectiveness of using ASB in diets for weight $\operatorname{loss}^{(38)}$, or even has associated their consumption with health damage such as diabetes ${ }^{(22,39)}$, dementia and stroke ${ }^{(40)}$. Following the high level of SB consumption, all these conditions are widely present in the Brazilian population. In 2016, more than half of the adult population in the state capitals and FD was overweight $\left(56 \cdot 5 \%\right.$ ), while $23 \cdot 1 \%$ was obese ${ }^{(4)}$. Medical diagnosis of diabetes was referred by $8.9 \%^{(24)}$ and, in 2015 , CVD figured among the main causes of death ${ }^{(41)}$.

It is natural to believe that those conditions would be impacted by the reduction in the consumption of SB. Actions aiming to improve diet quality in the country have 
Table 3 Prevalence of the regular consumption ( $\geq 5 \mathrm{~d} /$ week) of sugar-sweetened beverages among the adult population (aged $\geq 18$ years) from the Brazilian capitals and Federal District by sociodemographic variables. VIGITEL, 2007-2016

\begin{tabular}{|c|c|c|c|c|c|c|c|c|c|c|c|c|}
\hline \multirow[b]{2}{*}{ Variables } & \multicolumn{10}{|c|}{ Prevalence of the regular consumption of sugar-sweetened beverages (\%) } & \multirow{2}{*}{$\begin{array}{l}\text { Incremental average, } \\
2007-2016 \text { (pp/year)‡ }\end{array}$} & \multirow[b]{2}{*}{$P$ value } \\
\hline & 2007 & 2008 & 2009 & 2010 & 2011 & 2012 & 2013 & 2014 & 2015 & 2016 & & \\
\hline \multicolumn{13}{|l|}{ Gender } \\
\hline Male & $31 \cdot 2$ & $27 \cdot 4$ & $26 \cdot 1$ & $27 \cdot 0$ & $28 \cdot 5$ & - & - & - & $20 \cdot 3$ & 17.5 & $-1 \cdot 24^{*}$ & 0.013 \\
\hline Female & $22 \cdot 1$ & $19 \cdot 2$ & $19 \cdot 9$ & $20 \cdot 7$ & $20 \cdot 2$ & - & - & - & $14 \cdot 1$ & $12 \cdot 3$ & $-1.00^{*}$ & 0.012 \\
\hline \multicolumn{13}{|l|}{ Age (years) } \\
\hline $18-24$ & 39.2 & 33.8 & 34.0 & 33.3 & $37 \cdot 1$ & - & - & - & 28.4 & $22 \cdot 9$ & $-1 \cdot 29^{*}$ & 0.040 \\
\hline $25-34$ & $32 \cdot 8$ & 29.9 & $28 \cdot 8$ & 30.5 & 29.2 & - & - & - & $22 \cdot 0$ & $19 \cdot 0$ & $-1 \cdot 39^{*}$ & 0.005 \\
\hline $35-44$ & $25 \cdot 4$ & 21.9 & $22 \cdot 1$ & $26 \cdot 0$ & 23.2 & - & - & - & $16 \cdot 0$ & $15 \cdot 0$ & $-1 \cdot 11^{*}$ & 0.037 \\
\hline $45-54$ & 19.9 & $16 \cdot 9$ & $16 \cdot 9$ & $16 \cdot 9$ & $19 \cdot 4$ & - & - & - & $12 \cdot 3$ & $10 \cdot 8$ & $-0.84^{*}$ & 0.037 \\
\hline $55-64$ & $12 \cdot 5$ & 13.5 & $12 \cdot 2$ & $11 \cdot 3$ & 14.4 & - & - & - & 9.0 & $8 \cdot 2$ & $-0.62^{*}$ & 0.041 \\
\hline$\geq 65$ & $12 \cdot 1$ & 7.9 & $10 \cdot 2$ & 9.5 & 9.5 & - & - & - & $7 \cdot 0$ & $7 \cdot 0$ & -0.30 & 0.121 \\
\hline \multicolumn{13}{|l|}{ Schooling (years) } \\
\hline $0-8$ & 24.5 & $21 \cdot 3$ & $20 \cdot 6$ & $21 \cdot 1$ & $22 \cdot 9$ & - & - & - & $14 \cdot 6$ & $13 \cdot 9$ & $-1.04^{*}$ & 0.017 \\
\hline $9-11$ & 30.9 & $26 \cdot 9$ & $26 \cdot 5$ & 28.0 & $27 \cdot 8$ & - & - & - & $21 \cdot 0$ & $17 \cdot 8$ & $-1 \cdot 17^{*}$ & 0.014 \\
\hline$\geq 12$ & $22 \cdot 4$ & $20 \cdot 2$ & $20 \cdot 9$ & $21 \cdot 4$ & $20 \cdot 3$ & - & - & - & $14 \cdot 3$ & $12 \cdot 1$ & $-1 \cdot 13^{*}$ & 0.006 \\
\hline \multicolumn{13}{|l|}{ Marital status } \\
\hline With partner & $28 \cdot 3$ & $25 \cdot 5$ & $24 \cdot 1$ & $24 \cdot 8$ & $25 \cdot 4$ & - & - & - & $18 \cdot 4$ & $16 \cdot 0$ & $-1 \cdot 18^{*}$ & 0.006 \\
\hline Without partner & 24.5 & $20 \cdot 6$ & 21.4 & 22.5 & $22 \cdot 6$ & - & - & - & $15 \cdot 3$ & $13 \cdot 3$ & $-1.07^{*}$ & 0.022 \\
\hline \multicolumn{13}{|l|}{ Geographic region } \\
\hline North and Northeast & $24 \cdot 1$ & $18 \cdot 1$ & $19 \cdot 0$ & $19 \cdot 4$ & $19 \cdot 4$ & - & - & - & $13 \cdot 4$ & $10 \cdot 5$ & $-1.03^{*}$ & 0.015 \\
\hline $\begin{array}{l}\text { Midwest, Southeast } \\
\text { and South }\end{array}$ & $27 \cdot 5$ & $25 \cdot 6$ & $24 \cdot 8$ & $25 \cdot 9$ & $26 \cdot 5$ & - & - & - & $18 \cdot 9$ & $17 \cdot 0$ & $-1 \cdot 14^{*}$ & 0.011 \\
\hline TOTAL & $26 \cdot 3$ & $23 \cdot 0$ & $22 \cdot 8$ & 23.6 & $24 \cdot 0$ & - & - & - & $16 \cdot 9$ & 14.7 & $-1 \cdot 11^{*}$ & 0.011 \\
\hline
\end{tabular}

VIGITEL, Surveillance System of Risk and Protective Factors for Chronic Diseases by Telephone Survey; pp, percentage points.

${ }^{\star} P<0.05$.

†Weighted percentage to adjust the sociodemographic distribution of the VIGITEL sample to the distribution of the adult population of each city estimated for each year of study.

¥Corresponding to the linear regression coefficient value of the indicator on the year of the survey.

been intensified in the past decade ${ }^{(42)}$, following the strengthening of primary health care $^{(43)}$ (including the incorporation of nutritionists in multidisciplinary teams in $\left.2008^{(44)}\right)$ and supported by a complex set of policies and frameworks ${ }^{(23,43,45-48)}$. The latest edition of the Dietary Guidelines for the Brazilian Population (2014) assertively recommends that ultra-processed foods (including SB) should be avoided ${ }^{(49)}$. All this allowed the incorporation of food and nutrition education activities and healthy eating promotion actions in the routine of primary health-care centres $^{(50)}$ and public schools ${ }^{(51)}$ through the country. Although up to the moment no specific policy focuses on SSB consumption reduction, general health and healthy eating promotion actions may contribute to the adoption of healthier attitudes by the population, which would explain the downward trend found in the present study ${ }^{(28-30,52,53)}$. In 2017 , a study found similar results in the Australian context ${ }^{(54)}$. Another possibility is that the rising rates of overweight and obesity would lead consumers to search for healthier options of beverages ${ }^{(55)}$. Meanwhile, the exact role of these actions on the reduction of SB consumption is unclear, since no large-scale effective study or concentrated effort against the consumption of these beverages has been conducted.

Structural changes might also have influenced the observed trends. Since 2015, Brazil is experiencing intense political tension and economic crisis, impacting both the price of food and the income of families, with potential reflection on SB consumption. In this period, the yearly accumulated inflation for SB price was $12.6 \%$ in 2015 , $9.0 \%$ in 2016 and $2.6 \%$ in 2017 (higher than the general index: $10.7 \%$ in $2015,5.4 \%$ in 2016 and $2.9 \%$ in 2017$)^{(56)}$. Currently, more than 50 million Brazilians (about $25 \%$ of the population) live below the poverty line (less than $\$$ US 5.50 per person per day) ${ }^{(57)}$ and 13 million are unemployed (13.1\%), partially reversing the results of a decade of strong economic development ${ }^{(58)}$.

Despite the observed reduction in consumption, $65.8 \%$ of the adult population still referred weekly consumption of SB in 2016 (24). Thus, the next step involves the adoption of strong regulatory actions (interventions made by the State in public and private economic activities) for the control and orientation of the market and protection of the public interest. The imposition of taxes and advertising restrictions over unhealthy foods and beverages was proposed by the WHO, as well as in several other forums (such as professional associations and governments), about a decade ago as important strategies to tackle the global obesity epidemic $^{(59,60)}$. In 2016, the WHO published a document entitled Taxes on Sugary Drinks: Why Do It?, inviting all countries to implement tax measures against the consumption of these beverages. This document brings together a basic set of evidence on taxation and its impacts, supporting measures capable of increasing the final price of these beverages by at least $20 \%{ }^{(61)}$. SB taxation has already been implemented in more than thirty countries ${ }^{(62)}$, such as 
Table 4 Average daily consumption of sweetened beverages (including sugar- and artificially sweetened beverages) among the adult population (aged $\geq 18$ years) from the Brazilian capitals and Federal District by sociodemographic variables. VIGITEL, 2007-2016

\begin{tabular}{|c|c|c|c|c|c|c|c|c|c|c|c|c|c|c|}
\hline \multirow[b]{2}{*}{ Variable } & \multicolumn{10}{|c|}{ Average daily consumption of sweetened beverages (ml/capita) } & \multirow{2}{*}{$\begin{array}{c}\text { Incremental average, } \\
\text { 2007-2016 } \\
\text { (pp/year) } \dagger\end{array}$} & \multirow[b]{2}{*}{$P$ value } & \multirow{2}{*}{$\begin{array}{c}\text { Incremental average, } \\
2012-2016 \\
\text { (pp/year) } \dagger\end{array}$} & \multirow[b]{2}{*}{$P$ value } \\
\hline & 2007 & 2008 & 2009 & 2010 & 2011 & 2012 & 2013 & 2014 & 2015 & 2016 & & & & \\
\hline \multicolumn{15}{|l|}{ Gender } \\
\hline Male & $500 \cdot 3$ & $418 \cdot 7$ & $418 \cdot 3$ & $408 \cdot 0$ & $424 \cdot 9$ & $407 \cdot 1$ & $389 \cdot 3$ & 351.4 & $362 \cdot 2$ & $327 \cdot 4$ & $-11 \cdot 37^{\star}$ & 0.001 & $-18 \cdot 65^{\star}$ & 0.018 \\
\hline Female & $362 \cdot 7$ & 318.5 & $317 \cdot 7$ & $324 \cdot 8$ & $319 \cdot 8$ & $316 \cdot 7$ & $294 \cdot 8$ & 294.2 & $275 \cdot 1$ & $247 \cdot 1$ & $-8 \cdot 32^{*}$ & 0.002 & $-15 \cdot 89^{*}$ & 0.008 \\
\hline \multicolumn{15}{|l|}{ Age (years) } \\
\hline $18-24$ & $509 \cdot 9$ & $446 \cdot 0$ & $448 \cdot 3$ & $419 \cdot 6$ & 462.9 & 445.4 & $405 \cdot 7$ & $382 \cdot 2$ & 394.7 & 350.6 & $-11 \cdot 24^{*}$ & 0.006 & $-20 \cdot 06^{\star}$ & 0.028 \\
\hline $25-34$ & $465 \cdot 3$ & $414 \cdot 3$ & $400 \cdot 6$ & $401 \cdot 3$ & 408.5 & 396.4 & 382.5 & 364.9 & 351.3 & 311.3 & $-10 \cdot 97^{\star}$ & 0.001 & $-20 \cdot 13^{\star}$ & 0.006 \\
\hline $35-44$ & $407 \cdot 8$ & $345 \cdot 1$ & 344.9 & 375.4 & $347 \cdot 0$ & $368 \cdot 8$ & 341.0 & 310.5 & $306 \cdot 6$ & $282 \cdot 7$ & $-8 \cdot 33^{\star}$ & 0.018 & $-20 \cdot 66^{\star}$ & 0.004 \\
\hline $45-54$ & $370 \cdot 7$ & 299.9 & $318 \cdot 2$ & $314 \cdot 2$ & $320 \cdot 1$ & 293.9 & 283.4 & $280 \cdot 7$ & 268.0 & $256 \cdot 4$ & $-7 \cdot 14^{\star}$ & 0.003 & $-9 \cdot 05^{\star}$ & 0.002 \\
\hline $55-64$ & $327 \cdot 5$ & $269 \cdot 1$ & $287 \cdot 7$ & 274.9 & $283 \cdot 3$ & $278 \cdot 8$ & $250 \cdot 9$ & $232 \cdot 2$ & $242 \cdot 0$ & $227 \cdot 2$ & $-7.04^{\star}$ & 0.005 & $-11 \cdot 21$ & 0.055 \\
\hline \multirow{2}{*}{\multicolumn{15}{|c|}{ 然 }} \\
\hline & & & & & & & & & & & & & & \\
\hline $0-8$ & 432.5 & 357.8 & $357 \cdot 2$ & 358.9 & $376 \cdot 0$ & 363.7 & 350.5 & 307.0 & 314.9 & 295.9 & $-8 \cdot 40^{*}$ & 0.009 & $-17 \cdot 13^{\star}$ & 0.023 \\
\hline $9-11$ & $450 \cdot 8$ & $397 \cdot 7$ & 386.4 & $396 \cdot 3$ & 398.9 & 377.0 & $366 \cdot 6$ & $357 \cdot 7$ & 347.9 & $301 \cdot 1$ & $-10 \cdot 20^{*}$ & 0.002 & $-17 \cdot 05^{\star}$ & 0.029 \\
\hline$\geq 12$ & $390 \cdot 3$ & $336 \cdot 4$ & $350 \cdot 6$ & $328 \cdot 2$ & $320 \cdot 9$ & 331.6 & 294.7 & 287.8 & 281.6 & $262 \cdot 9$ & $-10 \cdot 14^{\star}$ & $<0.001$ & $-15 \cdot 05^{\star}$ & 0.016 \\
\hline \multicolumn{15}{|l|}{ Marital status } \\
\hline With partner & 449.4 & 389.0 & $386 \cdot 7$ & $370 \cdot 8$ & 390.7 & 373.0 & 358.6 & 341.7 & 332.4 & 304.7 & $-9 \cdot 84^{*}$ & 0.001 & $-16 \cdot 28^{*}$ & 0.002 \\
\hline Without partner & $411 \cdot 7$ & 345.5 & $347 \cdot 2$ & $360 \cdot 1$ & $349 \cdot 1$ & $349 \cdot 0$ & $323 \cdot 3$ & $303 \cdot 1$ & $304 \cdot 1$ & $267 \cdot 8$ & $-9 \cdot 67^{\star}$ & 0.002 & $-18 \cdot 15^{\star}$ & 0.009 \\
\hline \multicolumn{15}{|l|}{ Geographic region } \\
\hline $\begin{array}{l}\text { North and } \\
\text { Northeast }\end{array}$ & $398 \cdot 9$ & $320 \cdot 0$ & $330 \cdot 9$ & $326 \cdot 8$ & $324 \cdot 6$ & $314 \cdot 7$ & $307 \cdot 3$ & $289 \cdot 2$ & $289 \cdot 2$ & $250 \cdot 7$ & $-8 \cdot 25^{\star}$ & 0.002 & $-14 \cdot 62^{*}$ & 0.021 \\
\hline $\begin{array}{l}\text { Midwest, } \\
\text { Southeast } \\
\text { and South }\end{array}$ & $446 \cdot 1$ & $392 \cdot 8$ & $385 \cdot 7$ & $385 \cdot 6$ & $395 \cdot 3$ & $385 \cdot 2$ & $360 \cdot 3$ & $340 \cdot 3$ & 334.9 & $306 \cdot 3$ & $-10 \cdot 40^{*}$ & 0.001 & $-18 \cdot 31^{*}$ & 0.003 \\
\hline TOTAL & $430 \cdot 4$ & 367.9 & $366 \cdot 8$ & 365.4 & $370 \cdot 8$ & $361 \cdot 0$ & 341.9 & 322.9 & $319 \cdot 4$ & $287 \cdot 6$ & $-9 \cdot 63^{*}$ & 0.001 & $-16 \cdot 94^{*}$ & 0.004 \\
\hline
\end{tabular}

VIGITEL, Surveillance System of Risk and Protective Factors for Chronic Diseases by Telephone Survey; pp, percentage points. ${ }^{\star} P<0.05$.

†Corresponding to the linear regression coefficient value of the indicator on the year of the survey.

Mexico $^{(63)}$, Chile ${ }^{(64)}$, France ${ }^{(65)}$, Hungary ${ }^{(66)}$ Barbados $^{(67)}$, the $\mathrm{UK}^{(68)}$ and the USA (not at national level) ${ }^{(69)}$, more intensely in the last few years ${ }^{(70,71)}$. In Mexico, the measure resulted in a $6 \%$ reduction in sales of taxed beverages, impacting all social classes, but more significantly on the lower income strata ${ }^{(63,72)}$.

In Brazil, in August 2017, the Minister of Health declared himself in favour of adopting a tax on $\mathrm{SB}^{(73)}$ but little progress has been made so far due to the strong resistance of the beverage industry and federal legislators (largely financed by the food and beverage industry $)^{(74,75)}$. In a similar way, a federal initiative to regulate the advertising of unhealthy foods and beverages has been stalled since 2010 after industry litigation ${ }^{(76)}$. Without these types of measures, it is unclear if the federal government will be able to meet the target of reduction in SB consumption (at least $30 \%$ reduction in the prevalence of regular consumption from 2017 to 2019) assumed with the Pan American Health Organization/WHO in $2017^{(77)}$. A study conducted in 2012 indicates that an SSB tax would lead to a reduction in consumption in $\mathrm{Brazil}^{(78)}$. More recently (2017), a research that tested the impact of and adherence to food regulation proposals revealed that more than $70 \%$ of the population would consume less SB if there were a higher tax and price rises ${ }^{(79)}$.

Some limitations regarding the data set used for the present study should be considered. The questionnaire adopted by VIGITEL is composed by closed, short and objective questions, and do not allow detailed quantitative and qualitative evaluation of the studied factors. The indicator adopted for monitoring the consumption of $\mathrm{SB}$ does not include, for example, nectars and other mixed beverages. However, this questionnaire was specially developed to be applied by telephone interview in large population samples (more than 50000 interviews per year) ${ }^{(24)}$ and is frequently used in large surveys of health and lifestyle conditions due to its simplicity and low $\operatorname{cost}^{(80,81)}$. Similar methods are adopted by other health surveys conducted by telephone interview, such as the Behavioral Risk Factor Surveillance System (BRFSS) ${ }^{(82)}$, or for the investigation of a large number of risk factors, like the WHO STEPwise approach (STEPS) ${ }^{(83)}$. Although the questionnaire used by VIGITEL was not fully validated, all studies conducted up to this moment ensured the validity of data concerning dietary intake ${ }^{(84,85)}$. It is also worth noticing that although no other data on the consumption of SB are available in Brazil to validate our results (since the country has only one national food consumption survey, conducted in $2008 / 09^{(6)}$, making any trend analysis impossible), market studies (based on Euromonitor data) ${ }^{(86)}$ and industry balances ${ }^{(26-30)}$ provided similar conclusions, highlighting the declining trend in consumption of SB in the country.

Also, it is known that self-reported data about food consumption are more subject to inaccuracies, such as under-reporting, than those directly collected by the researcher. However, the present study analyses data about the consumption of a very limited set of beverages. This way, errors in reporting are much smaller than those observed in energy intake evaluations (given that energy is present in almost everything we ingest). Besides their limitations, self-report data are of great value to ground the identification of dietary patterns and to lead to diet-related associations that might inform nutrition policy ${ }^{(87)}$. 
Table 5 Prevalence $\dagger$ of non-consumption of sweetened beverages among the adult population (aged $\geq 18$ years) from the Brazilian capitals and Federal District by sociodemographic variables. VIGITEL, 2007-2016

\begin{tabular}{|c|c|c|c|c|c|c|c|c|c|c|c|c|c|c|}
\hline \multirow[b]{2}{*}{ Variable } & \multicolumn{10}{|c|}{ Prevalence of non-consumption of sweetened beverages (\%) } & \multirow{2}{*}{$\begin{array}{c}\text { Incremental average, } \\
\text { 2007-2016 } \\
\text { (pp/year) } \ddagger\end{array}$} & \multirow[b]{2}{*}{$P$ value } & \multirow{2}{*}{$\begin{array}{c}\text { Incremental average, } \\
\text { 2012-2016 } \\
\text { (pp/year) } \ddagger\end{array}$} & \multirow[b]{2}{*}{$P$ value } \\
\hline & 2007 & 2008 & 2009 & 2010 & 2011 & 2012 & 2013 & 2014 & 2015 & 2016 & & & & \\
\hline \multicolumn{15}{|l|}{ Gender } \\
\hline Male & $25 \cdot 9$ & 21.9 & $20 \cdot 9$ & $19 \cdot 1$ & $20 \cdot 0$ & $21 \cdot 2$ & $25 \cdot 1$ & $27 \cdot 8$ & $31 \cdot 1$ & $28 \cdot 0$ & $1 \cdot 29^{*}$ & 0.005 & 1.95 & 0.080 \\
\hline $\begin{array}{l}\text { Female } \\
\text { Age (years) }\end{array}$ & 34.3 & $31 \cdot 2$ & $29 \cdot 2$ & 27.5 & $27 \cdot 5$ & 29.9 & 35.5 & 38.6 & 43.0 & 39.5 & $1.76^{\star}$ & 0.005 & 2.67 & 0.063 \\
\hline $18-24$ & $13 \cdot 5$ & $12 \cdot 4$ & 10.9 & $10 \cdot 7$ & $10 \cdot 4$ & $12 \cdot 9$ & $15 \cdot 8$ & $18 \cdot 8$ & $20 \cdot 2$ & $20 \cdot 7$ & $1 \cdot 38^{\star}$ & 0.001 & $1.99^{\star}$ & 0.008 \\
\hline $25-34$ & 20.5 & $17 \cdot 0$ & $16 \cdot 1$ & $13 \cdot 2$ & $15 \cdot 0$ & $15 \cdot 8$ & $19 \cdot 7$ & 23.6 & $26 . \overline{9}$ & $26 \cdot 0$ & $1.56^{\star}$ & 0.004 & $2 \cdot 76^{\star}$ & 0.017 \\
\hline $35-44$ & $29 \cdot 3$ & $23 \cdot 3$ & $22 \cdot 0$ & $20 \cdot 2$ & $21 \cdot 3$ & 23.9 & $27 \cdot 0$ & 28.9 & $33 \cdot 8$ & $30 \cdot 5$ & $1.46^{*}$ & 0.003 & 2.00 & 0.065 \\
\hline $45-54$ & 38.3 & 34.7 & 32.7 & 28.9 & 29.0 & 30.9 & $37 \cdot 6$ & 38.6 & 44.5 & 39.8 & $1 \cdot 39^{\star}$ & 0.031 & $2 \cdot 47$ & 0.108 \\
\hline $55-64$ & $50 \cdot 3$ & 43.0 & $41 \cdot 8$ & 41.3 & $37 \cdot 3$ & 41.5 & $47 \cdot 6$ & $50 \cdot 3$ & 54.4 & $48 \cdot 3$ & $1.45^{\star}$ & 0.024 & 2.06 & 0.195 \\
\hline$\geq 65$ & $56 \cdot 5$ & $56 \cdot 3$ & $51 \cdot 0$ & $50 \cdot 9$ & $51 \cdot 7$ & $49 \cdot 8$ & $57 \cdot 4$ & 61.5 & 63.4 & $53 \cdot 3$ & 0.87 & $0 \cdot 189$ & $1 \cdot 30$ & 0.546 \\
\hline \multicolumn{15}{|l|}{ Schooling (years) } \\
\hline $0-8$ & 38.6 & 33.9 & 31.6 & $30 \cdot 4$ & $31 \cdot 2$ & 31.9 & 37.9 & 41.4 & $45 \cdot 1$ & $38 \cdot 6$ & $1.46^{*}$ & 0.015 & 2.07 & 0.213 \\
\hline $9-11$ & 23.7 & 20.9 & $20 \cdot 3$ & $19 \cdot 3$ & $18 \cdot 8$ & $21 \cdot 4$ & $25 \cdot 8$ & $27 \cdot 8$ & 31.6 & 29.5 & $1.53^{*}$ & 0.002 & $2 \cdot 21^{\star}$ & 0.041 \\
\hline$\geq 12$ & 23.9 & $22 \cdot 3$ & $21 \cdot 7$ & $18 \cdot 6$ & $20 \cdot 4$ & $24 \cdot 1$ & $27 \cdot 8$ & 31.6 & $36 \cdot 2$ & $35 \cdot 0$ & $2 \cdot 13^{\star}$ & 0.001 & $3.02^{*}$ & 0.013 \\
\hline \multicolumn{15}{|c|}{ 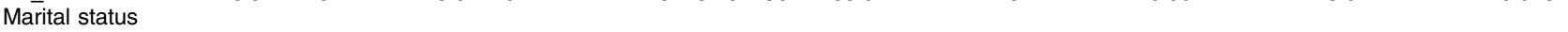 } \\
\hline With partner & $27 \cdot 4$ & 24.5 & $23 \cdot 7$ & $22 \cdot 0$ & $21 \cdot 8$ & $24 \cdot 3$ & $28 \cdot 7$ & 31.6 & $35 \cdot 6$ & 32.5 & $1.57^{\star}$ & 0.004 & $2 \cdot 31$ & 0.060 \\
\hline Without partner & 33.2 & 29.3 & 26.9 & $25 \cdot 2$ & $26 \cdot 4$ & $27 \cdot 4$ & $32 \cdot 8$ & $35 \cdot 7$ & $39 \cdot 7$ & $36 \cdot 1$ & $1.55^{\star}$ & 0.007 & 2.42 & 0.077 \\
\hline \multicolumn{15}{|l|}{ Geographic region } \\
\hline $\begin{array}{l}\text { North and } \\
\text { Northeast }\end{array}$ & $31 \cdot 2$ & $28 \cdot 0$ & 26.5 & $24 \cdot 6$ & $24 \cdot 8$ & $27 \cdot 4$ & 31.4 & $35 \cdot 7$ & $39 \cdot 7$ & $37 \cdot 3$ & $1 \cdot 76^{\star}$ & 0.004 & $2 \cdot 80^{\star}$ & 0.035 \\
\hline $\begin{array}{l}\text { Midwest, } \\
\text { Southeast } \\
\text { and South }\end{array}$ & $30 \cdot 0$ & $26 \cdot 3$ & $24 \cdot 8$ & $23 \cdot 1$ & $23 \cdot 6$ & $25 \cdot 1$ & $30 \cdot 4$ & $32 \cdot 5$ & $36 \cdot 3$ & $32 \cdot 6$ & $1.42^{*}$ & 0.007 & $2 \cdot 08$ & 0.103 \\
\hline TOTAL & 30.4 & $26 \cdot 9$ & 25.4 & $23 \cdot 6$ & 24.0 & 25.9 & 30.7 & 33.7 & 37.5 & $34 \cdot 2$ & $1.54^{*}$ & 0.005 & $2 \cdot 32$ & 0.069 \\
\hline
\end{tabular}

VIGITEL, Surveillance System of Risk and Protective Factors for Chronic Diseases by Telephone Survey; pp, percentage points.

${ }^{*} P<0.05$.

tWeighted percentage to adjust the sociodemographic distribution of the VIGITEL sample to the distribution of the adult population of each city estimated for each year of study.

¥Corresponding to the linear regression coefficient value of the indicator on the year of the survey.

\section{Conclusion}

The present study demonstrated a downward trend in the consumption of SB among adults in the Brazilian capitals and FD between 2007 and 2016. Even so, these beverages are still consumed virtually daily by a significant portion of the Brazilian adult population, being a generous source of free sugars in their diet. The adoption of strong regulatory actions including the regulation of advertising of unhealthy foods and beverages as well as fiscal policies could contribute for Brazil to reduce, even more, the consumption of SB.

\section{Acknowledgements}

Acknowledgements: The authors are grateful to Conselho Nacional de Desenvolvimento Científico e Tecnológico (CNPq) and Fundação de Amparo à Pesquisa de Minas Gerais (FAPEMIG) for financial support and granting scholarships. Financial support: This work was supported by Ministério da Ciência, Tecnologia e Inovação, CNPq (grant numbers 309293/2016-2 and 407331/2016-6); and FAPEMIG (grant numbers APQ-02329-15 - 01/2015 and PPM-00325-17 - 02/2017). The funding agencies had no role in the design, analysis or writing of this article. Conflict of interest: The authors declare no conflicts of interest. Authorship: N.F., E.G.M. and R.M.C. conceptualized the study and drafted and revised the manuscript. L.E.S.S. performed the statistical analysis and revised the manuscript. F.S.G. revised the manuscript. Ethics of buman subject participation: The VIGITEL was approved by the National Commission of Ethics in Research for Human Beings of the Ministry of Health (CONEP Opinion 355.590 of 26 June 2013 and certificate of presentation for ethics assessment (CAAE) no. 16202813.2.0000.0008). Data are freely available for public access and use and do not allow the identification of the respondents.

\section{References}

1. Ministry of Health of Brazil (2011) Plano de Ações Estratégicas para o Enfrentamento das Doenças Crônicas Não Transmissiveis (DCNT) no Brasil 2011-2022. Brasília, DF: Ministério da Saúde.

2. World Health Organization (2010) Assessing National Capacity for the Prevention and Control of Noncommunicable Diseases. Geneva: WHO.

3. Malta DC, Campos MO, Oliveira MM et al. (2015) Prevalência de fatores de risco e proteção para doenças crônicas não transmissíveis em adultos residentes em capitais brasileiras, 2013. Epidemiol Serv Saude 24, 373-387.

4. Institute of Health Metrics and Evaluation (2017) GBD Compare. https://vizhub.healthdata.org/gbd-compare (accessed October 2017).

5. World Health Organization (2003) Diet, Nutrition and the Prevention of Chronic Diseases. Joint WHO/FAO Expert Consultation. WHO Technical Report Series no. 916. Geneva: WHO.

6. Brazilian Institute of Geography and Statistics (2010) Household Budget Survey 2008-2009: Expenditure Profile in Brazil - Selected Indicators. Rio de Janeiro, RJ: IBGE. 
7. Ng M, Fleming T, Robinson M et al. (2014) Global, regional and national prevalence of overweight and obesity in children and adults 1980-2013: a systematic analysis. Lancet 384, 766-781.

8. GBD 2015 Obesity Collaborators (2017) Health effects of overweight and obesity in 195 countries over 25 years. $N$ Engl J Med 377, 13-27.

9. Kac G \& Pérez-Escamilla R (2013) Nutrition transition and obesity prevention through the life-course. Int J Obes Suppl 3, Suppl. 1, S6-S8.

10. World Health Organization (2015) Guideline: Sugars Intake for Adults and Cbildren. Geneva: WHO.

11. Martins APB, Levy RB, Claro RM et al. (2013) Increased contribution of ultra-processed food products in the Brazilian diet (1987-2009). Rev Saude Publica 47, 656-665.

12. Hu FB (2013) Resolved: there is sufficient scientific evidence that decreasing sugar-sweetened beverage consumption will reduce the prevalence of obesity and obesityrelated diseases. Obes Rev 14, 606-619.

13. Malik VS \& Hu FB (2015) Fructose and cardiometabolic health. What the evidence from sugar-sweetened beverages tells us. I Am Coll Cardiol 66, 1615-1624.

14. Xi B, Huang Y, Reilly KH et al. (2016) Sugar-sweetened beverages and risk of hypertension and CVD: a doseresponse meta-analysis. Br J Nutr 113, 709-717.

15. Luger M, Lafontan M, Bes-Rastrollo M et al. (2017) Sugarsweetened beverages and weight gain in children and adults: a systematic review from 2013 to 2015 and a comparison with previous studies. Obes Facts 10, 674-693.

16. Popkin BM (2010) Contemporary nutritional transition: determinants of diet and its impact on body composition. Proc Nutr Soc 70, 82-91.

17. Drewnowisk A \& Rehm CD (2014) Consumption of added sugars among US children and adults by food purchase location and food source. Am J Clin Nutr 100, 901-907.

18. Stern D, Piernas C, Barquera S et al. (2014) Caloric beverages were major sources of energy among children and adults in Mexico, 1999-2012. J Nutr 144, 949-956.

19. Ha K, Chung S, Lee HS et al. (2016) Association of dietary sugars and sugar-sweetened beverage intake with obesity in Korean children and adolescents. Nutrients $\mathbf{8}, \mathrm{E} 31$.

20. Levy RB, Claro RM, Bandoni DH et al. (2012) Availability of added sugars in Brazil: distribution, food sources and time trends. Rev Bras Epidemiol 15, 3-12.

21. Ebbeling CB, Feldman HA, Chomitz VR et al. (2012) A randomized trial of sugar-sweetened beverages and adolescent body weight. $N$ Engl J Med 367, 1407-1416.

22. Imamura F, O'Connor L, Ye Z et al. (2015) Consumption of sugar sweetened beverages, artificially sweetened beverages, and fruit juice and incidence of type 2 diabetes: systematic review, meta-analysis, and estimation of population attributable fraction. BMJ 351, h3576.

23. Ministério do Desenvolvimento Social e Combate à Fome (2014) Estratégia Intersetorial de Prevenção e Controle da Obesidade: Recomendações para Estados e Municípios. Brasília, DF: CAISAN.

24. Ministry of Health of Brazil (2017) Surveillance System of Risk and Protective Factors for Chronic Diseases by Telephone Survey - VIGITEL 2016. Brasília, DF: Ministério da Saúde.

25. Khan TA \& Sievenpiper JL (2016) Controversies about sugars: results from systematic reviews and meta-analyses on obesity, cardiometabolic disease and diabetes. Eur J Nutr 55, Suppl. 2, S25-S43.

26. Associação Brasileira das Indústrias de Refrigerantes e Bebidas não Alcóolicas (2018) Volume de produção do mercado brasileiro de refrigerantes dos anos de 2010 a $2016 . \quad$ https://abir.org.br/o-setor/dados/refrigerantes/ (accessed June 2018).
27. Associação Brasileira das Indústrias de Refrigerantes e Bebidas não Alcóolicas (2016) Produção de refrigerantes tem o pior início de ano desde 2012. https://abir.org.br/ producao-de-refrigerantes-tem-o-pior-inicio-de-ano-desde2012/ (accessed June 2018).

28. Folha de São Paulo (2014) Refrigerantes perdem espaço no mercado brasileiro de bebidas. https://www1.folha.uol. com.br/mercado/2014/09/1515705-refrigerantes-perdemespaco-no-mercado-brasileiro-de-bebidas.shtml (accessed June 2018).

29. Valor Econômico (2016) Retração em refrigerantes veio para ficar. http://www.valor.com.br/empresas/4673589/ retracao-em-refrigerantes-veio-para-ficar (accessed June 2018).

30. Jornal do Comércio (2017) Setor de refrigerantes perde espaço no país. http://www.jornaldocomercio.com/_con teudo/2017/02/economia/546323-setor-de-refrigerantesperde-espaco-no-pais.html (accessed June 2018).

31. Ministry of Health of Brazil (2018) DATASUS. Projeção da população residente por idade simples segundo ano. http://tabnet.datasus.gov.br/cgi/tabcgi.exe?ibge/cnv/projpopbr. def (accessed January 2018).

32. Lim L, Banwell C, Bain C et al. (2014) Sugar sweetened beverages and weight gain over 4 years in a Thai national cohort - a prospective analysis. PLoS One 9, e95309.

33. Laverty AA, Magee L, Monteiro CA et al. (2015) Sugar and artificially sweetened beverage consumption and adiposity changes: national longitudinal study. Int J Behav Nutr Phys Act 12, 137.

34. Schulze MB, Manson JE, Ludwig DS et al. (2004) Sugarsweetened beverages, weight gain and incidence of type 2 diabetes in young and middle-aged women. JAMA 292, 927-934.

35. Odegaard AO, Koh WP, Arakawa K et al. (2010) Soft drink and juice consumption and risk of physician-diagnosed incident type 2 diabetes: the Singapore Chinese Health Study. Am J Epidemiol 171, 701-708.

36. Mozaffarian D, Hao T, Rimm EB et al. (2011) Changes in diet and lifestyle and long-term weight gain in women and men. $N$ Engl J Med 364, 2392-2404.

37. Narain A, Kwok CS \& Mamas MA (2016) Soft drinks and sweetened beverages and the risk of cardiovascular disease and mortality: a systematic review and meta-analysis. Int J Clin Pract 70, 791-805.

38. Borges MC, Louzada ML, Sá TH et al. (2017) Artificially sweetened beverages and the response to the global obesity crisis. PLoS Med 14, e1002195.

39. Yarmolinsky J, Duncan BB, Chambless LE et al. (2016) Artificially sweetened beverage consumption is positively associated with newly diagnosed diabetes in normal-weight but not in overweight or obese Brazilian adults. J Nutr 146 , 290-297.

40. Pase MP, Himali JJ, Beiser AS et al. (2017) Sugar- and artificially sweetened beverages and the risks of incident stroke and dementia: a prospective cohort study. Stroke 48, 11391146.

41. Lotufo PA, Goulard AC, Passos VMA et al. (2017) Cerebrovascular disease in Brazil from 1990 to 2015: Global Burden of Disease 2015. Rev Bras Epidemiol 20, Suppl. 1, S129-S141.

42. Boog MCF (1997) Nutritional education: past, present and future. Rev Nutr Campinas 10, 5-19.

43. Ministry of Health of Brazil (2012) Politica Nacional de Atenção Básica. Brasília, DF: Ministério da Saúde.

44. Ministry of Health of Brazil (2014) Cadernos de Atenção Básica: Núcleo de Apoio à Saúde da Família. Vol. 1. Brasília, DF: Ministério da Saúde, Departamento de Atenção Básica.

45. Ministry of Health of Brazil (2012) National Food and Nutrition Policy (PNAN). Brasília, DF: Ministério da Saúde. 
46. Ministério do Desenvolvimento Social e Combate à Fome (2012) Marco de Referência de Educação Alimentar e Nutricional para as Políticas Públicas. Brasília, DF: Ministério do Desenvolvimento Social e Combate à Fome.

47. Departamento de Educação Popular e Mobilização Cidadã (2014) Marco de Referência da Educação Popular para as Políticas Públicas. Rio de Janeiro, RJ: Departamento de Educação Popular e Mobilização Cidadã.

48. Ministério da Saúde, Departamento de Atenção Básica (2017) Promoção da Saúde e da Alimentação Adequada e Saudável. http://dab.saude.gov.br/portaldab/ape_promocao_ da_saude.php (accessed October 2017).

49. Ministry of Health of Brazil (2015) Dietary Guidelines for the Brazilian Population. Brasília, DF: Ministério da Saúde.

50. Conselho Federal de Nutricionistas (2008) O Papel do Nutricionista na Atenção Primária à Saúde. Brasília, DF: CFN.

51. Ministério da Saúde, Departamento de Atenção Básica (2018) Programa Saúde na Escola (PSE). http://dab.saude. gov.br/portaldab/pse.php (accessed January 2018).

52. Vox Media (2015) Brazil has the best nutritional guidelines in the world. https://www.vox.com/2015/2/20/8076961/ brazil-food-guide (accessed June 2018).

53. Ministry of Health of Brazil (2018) Apesar de obesidade em alta, pesquisa mostra brasileiros mais saudáveis. http:// portalms.saude.gov.br/noticias/agencia-saude/43604-apesarde-obesidade-em-alta-pesquisa-mostra-brasileiros-mais-saudaveis (accessed June 2018)

54. Brand-Miller JC \& Barclay AW (2017) Declining consumption of added sugars and sugar-sweetened beverages in Australia: a challenge for obesity prevention. Am J Clin Nutr 105, 854-863.

55. Estadão (2018) Obesidade atinge um em cada cinco adultos, mas dá sinais de estagnação. https://saude.estadao.com.br/ noticias/geral,obesidade-atinge-um-em-cada-cinco-adultosmas-da-sinais-de-estagnacao,70002353987 (accessed June 2018).

56. Brazilian Institute of Geography and Statistics (2018) Sistema Nacional de Índices de Preços ao Consumidor. Índice Nacional de Preços ao Consumidor Amplo. http://www. sidra.ibge.gov.br/snipc/tabelaINPC.asp (accessed June 2018).

57. Brazilian Institute of Geography and Statistics (2017) Síntese de Indicadores Sociais - SIS. https://www.ibge.gov.br/esta tisticas-novoportal/sociais/saude/9221-sintese-de-indicadoressociais.html?=\&t=o-que-e (accessed June 2018).

58. Agência Brasil (2018) Taxa de desemprego sobe para $13,1 \%$, diz pesquisa do IBGE. http://agenciabrasil.ebc.com.br/economia/noticia/2018-04/taxa-de-desempregosobe-para-131-diz-pesquisa-do-ibge (accessed June 2018).

59. Word Cancer Research Fund International (2017) Use Economic Tools to Address Affordability and Purchase Incentives. London: WCFR.

60. The Food Foundation (2017) UK's Restrictions on Junk Food Advertising to Children. London: Food Foundation.

61. World Health Organization (2016) Taxes on Sugary Drinks: Why Do It? Geneva: WHO.

62. Global Food Research Program (2017) Sugary Drinks Taxes: Africa, Middle East, Asia, and Pacific. Chapel Hill, NC: University of North Carolina.

63. Colchero MA, Popkin BM, Rivera JA et al. (2016) Beverage purchases from stores in Mexico under the excise tax on sugar sweetened beverages: observational study. BMJ 352, h6704.

64. Caro JC, Ng SW, Taillie SL et al. (2017) Designing a tax to discourage unhealthy food and beverage purchases: the case of Chile. Food Policy 71, 86-100.

65. Julia C, Mejean C, Vicari F et al. (2015) Public perception and characteristics related to acceptance of the sugar- sweetened beverage taxation launched in France in 2012. Public Health Nutr 18, 2679-2688.

66. Holt E (2011) Hungary to introduce broad range of fat taxes. Lancet 378, 755.

67. Alvarado M, Kostova D, Suhrcke M et al. (2017) Trends in beverage prices following the introduction of a tax on sugarsweetened beverages in Barbados. Prev Med 105, Suppl., S23-S25.

68. GOV.UK (2017) Soft Drinks Industry Levy. https://www. gov.uk/guidance/soft-drinks-industry-levy (accessed November 2017)

69. Falbe J, Thompson HR, Becker CM et al. (2016) Impact of the Berkeley excise tax on sugar-sweetened beverage consumption. Am J Public Health 106, 1865-1871.

70. Backholer K, Blake M \& Vandevijvere S (2016) Have we reached a tipping point for sugar-sweetened beverage taxes? Public Health Nutr 19, 3057-3061.

71. Backholer K, Blake M \& Vandevijvere S (2017) Sugarsweetened beverage taxation: an update on the year that was 2017. Public Health Nutr 20, 3219-3224.

72. Colchero MA, López CMG, Molina M et al. (2016) Beverages sales in Mexico before and after implementation of a sugar sweetened beverage tax. PLoS One 11, e0163463.

73. Folha de São Paulo (2017) Maior taxação de bebidas açucaradas seria medida 'saudável', diz ministro. http://www1. folha.uol.com.br/cotidiano/2017/08/1914133-maior-taxacaode-bebidas-acucaradas-seria-medida-saudavel-diz-ministro. shtml (accessed January 2018).

74. O Joio e o Trigo (2017) Presidente do PSDB usou o cargo para tratar de atividade como investidor da Coca. http:// outraspalavras.net/ojoioeotrigo/2017/10/presidente-dopsdb-usou-o-cargo-para-tratar-de-atividade-como-investidorda-coca/ (accessed January 2018).

75. O Joio e o Trigo (2017) Os bolsos gordos da ciência da obesidade: Como a indústria de alimentos ultraprocessados utiliza a pesquisa científica para minar políticas públicas, desviar o foco e promover hábitos de consume. http:// outraspalavras.net/ojoioeotrigo/2017/12/os-bolsos-gordosda-ciencia-da-obesidade/ (accessed January 2018).

76. Agência Nacional de Vigilância Sanitária (2010) Resolução $R D C N^{o} 24$, de 15 de junbo de 2010. Brasília, DF: ANVISA.

77. Interministerial Food and Nutrition Security Chamber (2015) Brazil's Commitments to the United Nations Decade of Action on Nutrition (2016-2025). Brasilia, DF: CAISAN.

78. Claro RM, Levy RB, Popkin BM et al. (2012) Sugarsweetened beverage taxes in Brazil. Am. J. Public Health 102, 178-183.

79. Folha de São Paulo (2017) Brasileiro tomaria menos 'refri' se preço fosse salgado, aponta pesquisa. https://www1.folha. uol.com.br/equilibrioesaude/2017/09/1917067-brasileirotomaria-menos-refri-se-preco-fosse-salgado-aponta-pesquisa. shtml (accessed June 2018).

80. Brener ND, Kann L, Kinchen SA et al. (2004) Methodology of the youth risk behavior surveillance system. MMWR Morb Mortal Wkly Rep 53, 1-13.

81. Brazilian Institute of Geography and Statistics (2014) National Adolescent School-Based Health Survey (PeNSE) 2013. Rio de Janeiro, RJ: IBGE.

82. Remington PL, Smith MY, Williamson DF et al. (1988) Design, characteristics, and usefulness of state-based behavioral risk factor surveillance: 1981-87. Public Health Rep 103, 366-375.

83. World Health Organization (2001) Summary: Surveillance of Risk Factors for Noncommunicable Diseases. The WHO STEPwise Approach. Geneva: WHO.

84. Monteiro CA, Moura EC, Jaime PC et al. (2008) Validity of food and beverage intake data obtained by telephone survey. Rev Saude Publica 42, 582-589.

85. Mendes LL, Campos SF, Malta DC et al. (2011) Validity and reliability of foods and beverages intake obtained by 
telephone survey in Belo Horizonte, Brazil. Rev Bras Epidemiol 14, 80-89.

86. O Estadão de São Paulo (2018) Busca por estilo de vida mais saudável pressiona indústria de alimentos no País. https://economia.estadao.com.br/noticias/geral,busca-por- estilo-de-vida-mais-saudavel-pressiona-industria-de-alimentosno-pais,70002259073 (accessed May 2018).

87. Subar AF, Freedman LS, Tooze JA et al. (2015) Addressing current criticism regarding the value of self-report dietary data. J Nutr 145, 2639-2645. 